\title{
Assessing the Effect of Integration in Logistics Sector on Economic Growth: Evidence from Sultanate of Oman
}

\author{
Ali Mohsin Salim Ba Awain ${ }^{1,2}$, Mohd Dan Jantan², \& Inda Sukati ${ }^{3}$ \\ ${ }^{1}$ Dhofar University Salalah, Sultanate of Oman \\ ${ }^{2}$ Infrastructure University Kuala Lumpur (IUKL), Malaysia \\ ${ }^{3}$ Researcher \\ Correspondence: College of Commerce and Business Administration, Dhofar University, Salalah, Sultanate of \\ Oman.
}

Received: October 25, 2021

Accepted: November 23, 2021

Online Published: December 7, 2021

doi:10.5539/ibr.v15n1p35

URL: https://doi.org/10.5539/ibr.v15n1p35

\begin{abstract}
Logistics has been recognized as an important weapon for competitive advantage to boost economic growth. This paper examines the integration in the logistics sector that may result in increasing the economic growth. The study is also considering the role of government policy on the relationship between the factors of integration and the economic growth. The finding of this study shows that there is positive effect of: (1) Infrastructure on economic growth, (2) productivity on economic growth, (3) competiveness on economic growth, (4) Technological Advancement on economic growth. This study also found that (5) The Relationship between infrastructure, productivity, competiveness, technological advancement on economic growth moderated by government policies
\end{abstract}

Keywords: logistic, infrastructure, productivity, economic growth, government policy

\section{Introduction}

Logistics driven by comprehensive and updated information flow, involves a range of extensive activity which secures transformation and distribution from source of raw material of goods to end user (Rodrigue, 2012). The CSMP has defined management logistics as a process of planning, implementing, and controlling of good, labor, information flow and storage from source of raw material for final customers (CSMP, 2013). Logistics system emphasizes organization of movement and distribution of required infrastructure and various flows such as material, finance and information in a given country (Navickas, 2011, Rodrigue, 2012).

\section{Literature Review}

\subsection{Infrastructure and Economic Growth}

In the literature, the relationship between infrastructure and economic growth is found to be unclear. However, much effort has been made within an econometric and input-output framework to estimate the linkage between infrastructure and economic growth (Tatyana Palei (2014)

Jin Zhoua et al (2021) argued that the investment in infrastructure is a typical fiscal tool to stimulate economic growth. It is considered that infrastructure impacts economic activities in three ways (Saygilı and Özdemir 2020) firstly, it directly contributes to production and employment through the enhancement of physical intermediaries, such as transportation and communication. Second, increase human capital and improve the social life of the community by providing better facilities such as education and health. Third, improve financial facilities such as financial transactions, loans, and other services. An increase in one type of infrastructure complements the development of another form of economic infrastructure (Jin Zhoua et al (2021). Moreover, the extensive literature suggests that continued large-scale infrastructure investment has weakened the capital-output share. This reduces investment efficiency and depletes economic resources (Banergee, Duflo, and Qian 2020; Cai and Ru 2016; Ouattara and Zhang 2019). Some studies (Jin Zhoua et al (2021) discuss the role of infrastructure in terms of growth efficiency, or sustainability, there is limited literature available that systematically attempts to assess the role of infrastructure from a growth quality perspective.

Improving the infrastructure is important to reduce the income gap and is a major determinant for the long run 
GDP per capita. Referring to the World Development Report's (World Bank, 2018), the sufficient infrastructure plays a significant influence toward the economic growth. The infrastructure program focused on increasing the basic human needs and connectivity, including clean water, electricity, energy, and transportation. However, the differences in the availability of physical and human capital within the countries play a role in explaining differences in economic growth between countries (Weil,2009)

\section{$H_{1}$ : There is positive linkage of Infrastructure on economic growth}

\subsection{Productivity and Economic Growth}

Productivity and economic growth are key factors in economic variables. Productivity depends on the availability and quality of resources and technologies used. As a result, productivity heavily influences the production process and production costs.

According to Suna Korkmaz \& Oya Korkmaz, (2017) the efficient use of resources is one of the important issues in the economy. Due to the scarcity of available resources, their efficient use is a necessity. There is a production level set can be attained if they use their resources with full and efficiency. Economic growth usually results from the accumulation of factor inputs in the production process. Economic growth can also occur when companies are able to increase output levels by using available inputs more efficiently and effectively. This step is achieved when the company increases productivity. Productivity can be assessed in terms of level and in terms of growth.

Koji Nakamura, Sohei Kaihatsu, Tomoyuki Yagi (2018) found that the slowdown of productivity affected by the decreasing of total production factors. There are two reasons behind the slowdown: first, technology and resources such as capital and manpower are not used efficiently; and second, these resources are not effectively allocated among companies. To increase productivity, it is necessary to capital and a flexible workforce by changing work processes at the corporate level in line with changes in the socio-economic environment and the emergence of new technologies.

\section{$\mathrm{H}_{2}$ : There is positive effect of productivity on economic growth}

\subsection{Competiveness and Economic Growth}

Porter (1990) argued that national competitiveness is one of the most important concerns for any countries (Lall, 2001,). National competitiveness is the ability of a country to sell its goods to other nations, as the ability of a country to acquire, as the ability to adapt to changes in the external environment and as the national ability to attract scarce resources (Berger, 2009).

Romana and Polona (2016) concluded that economic growth and consequently the standard of living of its population are related to many factors that are inside or outside the control of policymakers, institutions, companies and individuals. Although variously conceptualized and measured, a country's competitiveness comprises endogenous and exogenous variables of economic growth.

Aleksandra Kordalska and Magdalena Olczyk (2015) argue that global competiveness is a reliable predictor of economic growth. Moreover, Other researcher (Zagorsekova, et al (2018) found that there is positive relationship between competitiveness and economic growth.

\section{$H_{3}$ : There is positive effect of competiveness on economic growth}

\subsection{Technological Advancement and Economic Growth}

Technological developments are important factors that increase the rate of economic growth and profitability as well as market share of a company. Social development occurs if a society is able to make technological advances and reflect them to their social and cultural life. Technological development makes important contributions to our life. By developing the technology has simplified the human life. Broughel and Adam Thierer (2019) stated that Technological advancement is a fundamental driver of economic growth. (Fouzia Saeed et al, 2020) Technological innovation is an important driver of economic growth and human progress. (Majeed, M.T.; Ayub, T (2018) stated the information communication technology indicators and economic growth on regional and international level.

Some researchers study technological progress as one of the root causes of: Cyclical movement of capitalist economy, quantify the share of technological progress in the rate of GDP growth; Learn the importance of technological progress in the information society; Express the scientific and technological revolution (Krume Nikoloski, 2016). Gurgul, Henryk and Lach, Łukasz (2012). They investigate technological and economic growth: evidence from Poland and they found that technological advancement has a significant effect on economic growth. 


\section{$H_{4}:$ There is positive effect of Technological Advancement on economic growth}

2.5 The Role of Governmental Policies on the Relationship between Infrastructures, Productivity, Competiveness, Technological Advancement on Economic Growth

Lack of infrastructure impedes economic growth in many developing countries. Infrastructure investment has a contributing effect to increase productivity and contribute to future economic growth.

The role of government is to provide the needed infrastructure and create opportunities to boost economic growth. In many developing countries, existing capacity remains unused, not only due to a lack of adequate infrastructure, but also due to inadequate involvement of all parties involved in the planning and implementation process. Lack of necessary government intervention results in low productivity. Available policy instruments include possibilities such as public enterprises, accelerated depreciation provisions, low interest loans, subsidy programs, advance exemptions and reductions, tax concessions, incentives including tax holidays, and pioneer status for new types of business. All of this should be used effectively to accelerate and direct capital investment, driving economic growth and high productivity. But indiscriminate reliance on some of these instruments, particularly price controls, has proven unproductive in the long run (Joseph Prokopenko, 1998). Therefore, the role of government policies on the relationship between productivity and economic growth is important to elaborate in this research.

The role of government to increase economic growth has been much debated among many researchers. The issues that always arises is whether the role of government, through the composition of government spending or government consumption and excise, affects long -term economic growth. In the theory of the principle of economic growth, the neoclassical theory of Solow (1956) and Swan (1956), the answer to this issue is 'no' (Kneller et al., 1999). In this theory, the model is designed to show how the exogenous stock of capital, labor and technology affects economic growth. Although government can influence population growth, which in turn affects employment growth, this will not affect the long-term rate of per capita income growth (Kneller et al, 1999). In fact, the evidence is that in most developing countries it is difficult to lower population growth rates. The model also says that the level of savings affects the capital inventory and the level of output. This argument leads to a discussion of fiscal policy whether an increase in government spending will lead to a budget deficit and an increase in taxes will drive an increase in savings and lower domestic investment, then increase the level of national income (Mankiw, 2003).

There are many results in studying the relationship between fiscal policy and economic growth. Among those who argue that there is a positive relationship between government measures and economic growth are Rubinson (1977), Kormendi and Meguire (1985), and Barro (1990), who focus on productive production, and Kneller et.al (1999). Rubinson's (1977) study using the ratio of government income to GNI found that this ratio has a positive linkage with economic growth. He argued that this is especially true in developing countries when government spending offsets their dependence on other countries (Lin, 1994). In addition, Kormendi and Meguire (1985) also found a positive effect of government measures on economic growth. They use the average growth rate of the share of government consumption expenditure in GDP for 47 countries in World War II (Yin, 1994). His finding was followed by Barro (1990) but he found a significant positive effect only for productive government spending initially and then declining. Further, Kneller et al (1999) also observed the role of government in economic growth into two different perspectives, namely productive and unproductive government services. Productive government fiscal policy reflects spending and taxes that make a positive contribution to economic growth but not to unproductive fiscal policy.

$$
\begin{aligned}
& H_{5}: \quad \begin{array}{l}
\text { The Relationship between infrastructure and economic growth moderated by government } \\
\text { policies. }
\end{array} \\
& H_{6}: \quad \text { The Relationship between productivity and economic growth moderated by government policies. } \\
& H_{7}: \quad \begin{array}{l}
\text { The Relationship between Competiveness and economic growth moderated by government } \\
\text { policies. }
\end{array} \\
& H_{8}: \quad \begin{array}{l}
\text { The Relationship between technological advancement and economic growth moderated by } \\
\text { government policies. }
\end{array}
\end{aligned}
$$

\section{Methodology}

\subsection{Population and Sample}

The target population is the 778 logistics service company in Oman. the sampling frame is a list of all the logistics services in Oman in the 5 key sectors which include: air transport service, marine transport service, 
shipping and port agent, Land transport, transport agent. From the sampling frame, there were 5 key logistics service sectors of the 788 logistics service sectors in Oman. The logistics service sectors are divided into 5 groups/strata (See Table 1). The study involved a sample size of 152 based on this formula.

$$
n=\frac{Z^{2} p q^{N}}{e^{2}(N-1)+Z^{2} p q} \quad(\text { Pagano \& Gauvreau, 2000) }
$$

Table 1. Sample size

\begin{tabular}{|c|c|c|c|c|}
\hline Logistics service listing by sector & $\begin{array}{l}\text { No. of Logistics } \\
\text { service company }\end{array}$ & formula & $\begin{array}{r}\text { Strata } \\
\text { sample }\end{array}$ & $\begin{array}{c}\text { Stratum } \\
\text { percentage }\end{array}$ \\
\hline Air transport service & 72 & $152 * 72 / 788$ & 14 & $9 \%$ \\
\hline Marine transport service & 181 & $152 * 181 / 788$ & 35 & $23 \%$ \\
\hline Shipping and port agent service & 184 & $152 * 184 / 788$ & 36 & $23 \%$ \\
\hline Land Transport service & 275 & $152 * 275 / 788$ & 53 & $36 \%$ \\
\hline Transport agent service & 76 & $152 * 76 / 788$ & 14 & $9 \%$ \\
\hline Total & 788 & & 152 & $100 \%$ \\
\hline
\end{tabular}

\subsection{Data Collection}

This research has been conducted in Oman to investigate the infrastructure, productivity, competiveness, technology advancement on economic growth. This research also investigates the moderating role on government policies on the relationship between infrastructures, productivity, competiveness, technology advancement on economic growth. A research instrument is a tool used to obtain, measure, and analyses data from subjects around the research topic. Data collection are through the questionnaire five-item Likert scale as a mainly tool

\section{Statistical Results}

\subsection{Descriptive Statistics and Correlations}

This research focuses on logistics Service Company in Oman. The Logistics Services is a Logistics and Supply Chain management company with leadership in Project cargo, Freight Forwarding, Road freight, Customs Clearance and Warehousing Domain. They specialize in a total integrated Supply Chain solution to wide variety of Industry clients with a vast experience in real-world logistics and supply chain. They provide a highly optimized and customized logistics solution for every client requirement with high focus on efficiency. They offer a wide spectrum of services ranging from warehousing, transportation, freight forwarding, customs brokerage, consultancy \& management services and cargo quilts. Overland Transportation, Warehousing management and distribution Custom clearance, Documentation Import and Export - Freight Forwarding Supply Chain Consulting Services Bonded Warehousing Free Zone-To-Free zone operations Automated Vehicle Tracking System Customized Logistics solutions

The descriptive statistics for each of the variables are shown in Table 2, including their mean, standard deviation, minimum and maximum value and the correlation. Mean for the four composite independent variables are 100.7053 for infrastructure, 30.1368 for productivity, 48.1895 for competiveness, and 30.8947 for technology advancement respectively, with corresponding standard deviation (SD) of 14.25518, 5.52886, 8.56551, and 4.88698 respectively. Means of one dependent variable, economic growth was 11.74788 .

Table 2. Descriptive statistics of IV and DV

\begin{tabular}{|c|c|c|c|c|c|}
\hline & $\mathbf{N}$ & Min & Max & Mean & S.D \\
\hline Infrastructure (Inf) ( 23 item) & 95 & 35 & 115 & 100.7053 & 14.25518 \\
\hline Productivity (Prod) (7 items) & 95 & 7 & 35 & 30.1368 & 5.52886 \\
\hline Competiveness (Comp) (11 items) & 95 & 11 & 55 & 48.1895 & 8.56551 \\
\hline $\begin{array}{l}\text { Technology advancement (TA) ( } 7 \\
\text { items) }\end{array}$ & 95 & 11 & 35 & 30.8947 & 4.88698 \\
\hline Government policies (GP) ( 19 items) & 95 & 35 & 115 & 100.7053 & 14.25518 \\
\hline Economic growth (EG) (16 items) & 95 & 24 & 80 & 67.2000 & 11.74788 \\
\hline
\end{tabular}


Factors that influence the variance (VIF) were calculated to determine whether there are levels of multicollinearity. The decision was made based on tolerance value; if tolerance value more than 0.10 (no multicollinearity), if tolerance value less than 0.10 (serious multicollinearity). The VIF in this model has infrastructure (0.218), productivity (0.204) competiveness $(0.109)$ and technology advancement $(0.160)$. All tolerance value between independent variables that indicated that no serious multicollinearity.

Correlation techniques are used to explore the relationship and prove the relationship hypothetical two or more variables when the data forming the second variable interval or ratio, and source of data from two or more variables is the same. Correlation between independent variable (integration in logistic sector that consist of infrastructure, productivity, competiveness and technology advancement) and dependent variable (economic growth) is calculated and linier regression analysis is used in order to verify the correlation. In this research, Pearson's Product Moment of Coefficient Correlation, and simple correlation are applied to examine correlation and predict degree of integration in logistic sector and economic growth. The value of $r$ should range between 1.0 and 1.0 and determines the extent and type of correlation between the variable. A value close to extremities indicates a high correlation and indicates whether the correlation is negative or positive. A close to zero value indicates no correlation and a value in between indicate the existence of correlation to some moderate degree depending on the value.

Table 3 showed the correlation between independent variables (integration in logistics sector (infrastructure, productivity, competiveness and technology advancement) and moderating variable (government policies) was positive. infrastructure had a correlation of $0.752, \mathrm{p}<0.01$ with economic growth, productivity had a correlation of $0.638, \mathrm{p}<0.01$ with economic growth, competiveness had a correlation of $0.753, \mathrm{p}<0.01$ with economic growth, technology advancement had a correlation of $0.753, \mathrm{p}<0.01$ with economic growth.

The correlation got higher with economic growth when the moderator variables (government policies) interact with the independent variables (infrastructure, productivity, competiveness and technology advancement). The interaction of infrastructure and government policies (Inf X GP) scored the correlation of $0.796, \mathrm{p}<0.01$. The interaction of productivity and government policies (Prod X GP) scored the correlation of $0.771, \mathrm{p}<0.01$. The interaction of competiveness and government polices (Comp X GP) scored the correlation of 0.782, $\mathrm{p}<0.01$. The interaction of technology advancement and government policies (TA X GP) scored the correlation of 0.791 , $\mathrm{p}<0.01$.

These correlations mean that the moderating variable played significant role in the relationship between independent variables (infrastructure, productivity, competiveness and technology advancement) and dependent variables (economic growth)

Table 3. The correlation between IV and DV

\begin{tabular}{|c|c|c|c|c|c|c|c|c|c|c|}
\hline & \multicolumn{10}{|c|}{ Correlation } \\
\hline & 1 & 2 & 3 & 4 & 5 & 6 & 7 & 8 & 9 & 10 \\
\hline $\begin{array}{l}\text { Infrastructure } \\
\text { (Inf) }\end{array}$ & 1 & & & & & & & & & \\
\hline $\begin{array}{l}\text { Productivity } \\
\text { (Prod) }\end{array}$ & $\begin{array}{l}0.853 \\
* *\end{array}$ & 1 & & & & & & & & \\
\hline $\begin{array}{l}\text { Competiveness } \\
\text { (Comp) }\end{array}$ & $\begin{array}{l}0.853 \\
* *\end{array}$ & $\begin{array}{l}0.864 \\
* *\end{array}$ & 1 & & & & & & & \\
\hline $\begin{array}{l}\text { Technology } \\
\text { advancement } \\
\text { (TA) }\end{array}$ & $\begin{array}{l}0.801 \\
* *\end{array}$ & $\begin{array}{l}0.809 \\
* *\end{array}$ & $0.715 * *$ & 1 & & & & & & \\
\hline $\begin{array}{l}\text { Government } \\
\text { policies (GP) }\end{array}$ & $\begin{array}{l}0.875 \\
* *\end{array}$ & $\begin{array}{l}0.870 \\
* *\end{array}$ & $0.936 * *$ & $0.903 * *$ & 1 & & & & & \\
\hline Inf X GP & $\begin{array}{l}0.947 \\
* *\end{array}$ & $\begin{array}{l}0.878 \\
* *\end{array}$ & $0.909 * *$ & $0.867 * *$ & $0.960 * *$ & 1 & & & & \\
\hline Prod X GP & $\begin{array}{l}0.887 \\
* *\end{array}$ & $\begin{array}{l}0.959 \\
* *\end{array}$ & $0.930 * *$ & $0.860 * *$ & $0.942 * *$ & $\begin{array}{l}0.962 \\
* *\end{array}$ & 1 & & & \\
\hline Comp X GP & $\begin{array}{l}0.875 \\
* *\end{array}$ & $\begin{array}{l}0.866 \\
* *\end{array}$ & $0.970 * *$ & $0.904 * *$ & $0.970 * *$ & $0.967 * *$ & $0.951 * *$ & 1 & & \\
\hline TA X GP & $\begin{array}{l}0.856 \\
* *\end{array}$ & $\begin{array}{l}0.848 \\
* *\end{array}$ & $0.928 * *$ & $0.961 * *$ & $0.964 * *$ & $0.953 * *$ & $0.937 * *$ & $0.970 * *$ & 1 & \\
\hline $\begin{array}{l}\text { Economic } \\
\text { growth (EG) }\end{array}$ & $\begin{array}{l}0.752 \\
* *\end{array}$ & $\begin{array}{l}0.638 \\
* *\end{array}$ & $0.753 * *$ & $0.753 * *$ & $0.769 * *$ & $0.796 * *$ & $0.771 * *$ & $0.782 * *$ & $0.791 * *$ & 1 \\
\hline
\end{tabular}




\subsection{Hypotheses Testing}

\section{$\mathrm{H}_{1}$ : There is positive effect of Infrastructure on economic growth}

To test the $\left(\mathrm{H}_{1}\right)$, the regression analysis for infrastructure was conducted to determine the proportion of economic growth (dependent variable) which would be predicted by infrastructure (independent variable). The model seems to be reliable ( $\mathrm{p}$-value for $\mathrm{F}<0.01$ and adjusted R-square of 0.560 . The Model showed that $56 \%$ of economic growth is related to infrastructure. Therefore, infrastructure is a significant predictor of economic growth as shown in table 4 . Results in model Table 4 appear to confirm $\mathrm{H}_{1}$.

Table 4. Regression results of Infrastructure and Economic Growth

\begin{tabular}{|c|c|c|c|c|c|c|c|}
\hline \multirow{2}{*}{$\begin{array}{l}\text { Model } \\
1 \\
\text { ANOVA }\end{array}$} & \multirow[t]{2}{*}{$\begin{array}{l}\mathbf{R} \\
0752^{\mathrm{a}}\end{array}$} & \multicolumn{2}{|l|}{ R Square } & \multicolumn{2}{|c|}{$\begin{array}{l}\text { Adjusted R } \\
\text { Square }\end{array}$} & \multicolumn{2}{|l|}{$\begin{array}{l}\text { Std. } \\
\text { of ther } \\
\text { of the } \\
\text { estimate }\end{array}$} \\
\hline & & 0.565 & & \multicolumn{2}{|l|}{0.560} & \multicolumn{2}{|l|}{7.792} \\
\hline & & Sum of square & df & $\begin{array}{l}\text { Mean } \\
\text { square }\end{array}$ & F & \multicolumn{2}{|l|}{ Sig. } \\
\hline & Regression & 7327.240 & 1 & \multirow{2}{*}{$\begin{array}{l}7327.240 \\
60.709\end{array}$} & 120.694 & \multirow{2}{*}{\multicolumn{2}{|c|}{$0.00^{\mathrm{b}}$}} \\
\hline & Residual & 5645.960 & 93 & & & & \\
\hline & Total & \multicolumn{4}{|c|}{ Coefficients } & & \\
\hline & & $\begin{array}{l}\text { Unstandardized } \\
\text { B }\end{array}$ & \multicolumn{2}{|c|}{$\begin{array}{l}\text { Coefficients } \\
\text { Std. Error }\end{array}$} & $\begin{array}{l}\text { Standardized } \\
\text { Coefficients } \\
\text { Beta }\end{array}$ & $\mathrm{t}$ & Sig \\
\hline & Constant) & 4.829 & \multirow{2}{*}{\multicolumn{2}{|c|}{$\begin{array}{r}5.733 \\
0.056\end{array}$}} & & 0.842 & 0.402 \\
\hline & Infrastructure & 0.619 & & & 0.752 & 10.986 & 0.000 \\
\hline
\end{tabular}

a. DV: Economic growth

b. Predictors: (Constant) Infrastructure

\section{$H_{5}$ : Moderating effect of government policies on infrastructure and economic growth.}

This study identified government polices use as the moderator variable affecting the relationship between infrastructure (independent variable) and economic growth (dependent variable) among the logistic service firms in Oman. Using the moderated multiple regression (MMR) analysis in this study, the moderating effect of the variable (interaction term) was analyzed by interpreting the $\mathrm{R}^{2}$ change in the models obtained from the model summaries and by interpreting the regression coefficients for the interaction term obtained from the coefficient tables. Regression analysis was performed in this study to test the moderating effect of government policies on the relationship between infrastructure and economic growth.

Table 5 shows the regression between all integrated variable (independent and interaction) to examine the moderation effect on the relationship between infrastructure and government policies on economic growth. The adjusted coefficient of determination of the model is $R^{2} 0.630$ with $p$-value $<0.01$. As a result, the interaction term (Inf X GP) was significantly related to economic growth. The Model showed that $63 \%$ of economic growth is related to independent variables (infrastructure and interaction with government polices). Results in model Table 5 appear to confirm $\mathrm{H}_{5}$. 
Table 5. The moderating effect of government policies on infrastructure and Economic growth

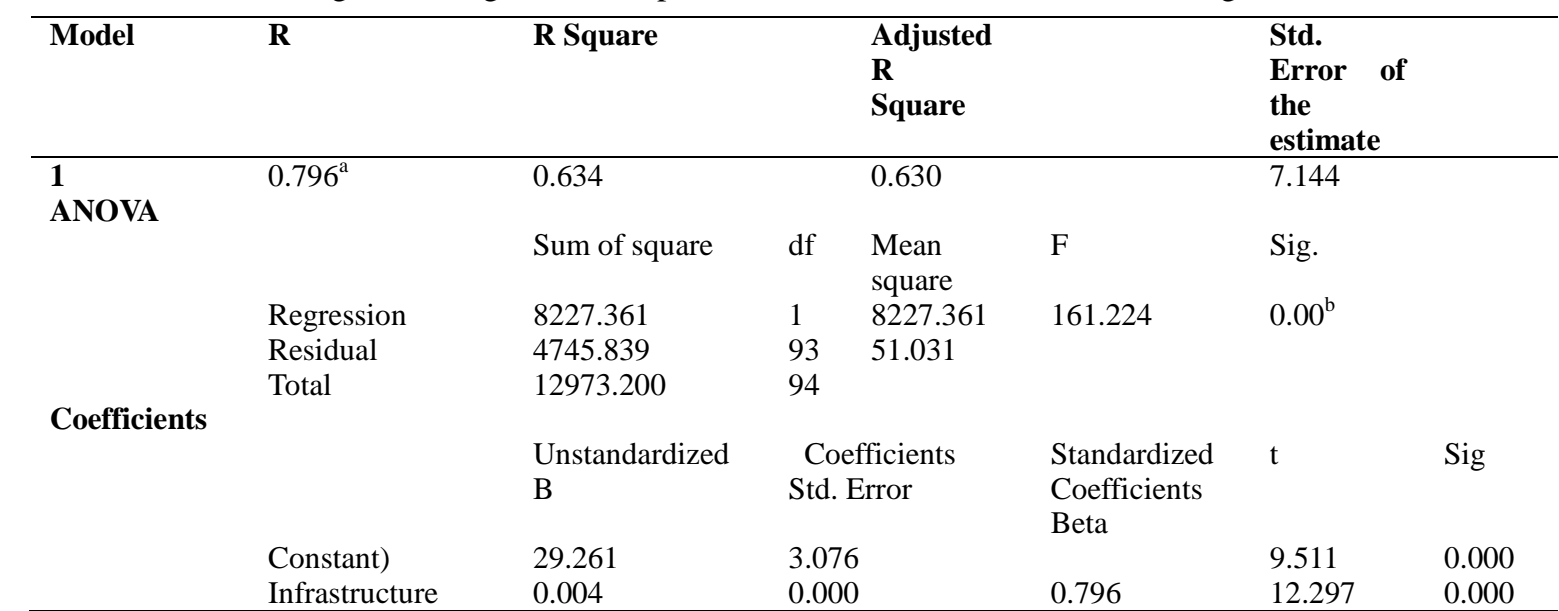

a. DV: Economic growth

b. Predictors: (Constant) InfxGP

\section{$\mathrm{H}_{2}$ : There is positive effect of productivity on economic growth}

To test the $\left(\mathrm{H}_{2}\right)$, the regression analysis for productivity was conducted to determine the proportion of economic growth (dependent variable) which would be predicted by productivity (independent variable). The model seems to be reliable ( $\mathrm{p}$-value for $\mathrm{F}<0.01$ and adjusted $\mathrm{R}$-square of 0.407 . The Model showed that $40.1 \%$ of economic growth is related to productivity. Therefore, productivity is a predictor of economic growth as shown in table 6 . Results in model Table 6 appear to confirm $\mathrm{H}_{2}$.

Table 6. Regression results of productivity and Economic Growth

\begin{tabular}{|c|c|c|c|c|c|c|c|}
\hline \multirow{2}{*}{$\begin{array}{l}\text { Model } \\
1 \\
\text { ANOVA }\end{array}$} & \multirow{2}{*}{$\begin{array}{l}\mathbf{R} \\
0.638^{\mathrm{a}}\end{array}$} & \multicolumn{2}{|l|}{ R Square } & \multicolumn{2}{|c|}{$\begin{array}{l}\text { Adjusted R } \\
\text { Square }\end{array}$} & \multicolumn{2}{|c|}{$\begin{array}{l}\text { Std. } \\
\text { Error } \\
\text { of the } \\
\text { estimate }\end{array}$} \\
\hline & & 0.407 & & \multicolumn{2}{|l|}{0.401} & \multicolumn{2}{|c|}{9.093} \\
\hline & & Sum of square & df & $\begin{array}{l}\text { Mean } \\
\text { square }\end{array}$ & F & \multicolumn{2}{|l|}{ Sig. } \\
\hline & Regression & 5283.942 & 1 & 5283.942 & 63.908 & \multicolumn{2}{|l|}{$0.00^{\mathrm{b}}$} \\
\hline & Residual & 7689.258 & 93 & 8.0260 & & & \\
\hline & Total & 12973.200 & \multicolumn{4}{|c|}{ Coefficients } & \\
\hline Coetricie & & $\begin{array}{l}\text { Unstandardized } \\
\text { B }\end{array}$ & \multicolumn{2}{|c|}{$\begin{array}{l}\text { Coefficients } \\
\text { Std. Error }\end{array}$} & $\begin{array}{l}\text { Standardized } \\
\text { Coefficients } \\
\text { Beta }\end{array}$ & $\mathrm{t}$ & Sig \\
\hline & Constant) & 36.331 & \multicolumn{2}{|c|}{5.197} & & 5.067 & 0.000 \\
\hline & Infrastructure & 2.356 & \multicolumn{2}{|c|}{0.170} & 0.638 & 7.994 & 0.000 \\
\hline
\end{tabular}

a. DV: Economic growth

b. Predictors: (Constant) productivity

\section{$H_{6}:$ The Relationship between productivity and economic growth moderated by government policies.}

This study identified government polices use as the moderator variable affecting the relationship between productivity (independent variable) and economic growth (dependent variable) among the logistic service firms in Oman. Using the moderated multiple regression (MMR) analysis in this study, the moderating effect of the variable (interaction term) was analyzed by interpreting the $\mathrm{R}^{2}$ change in the models obtained from the model summaries and by interpreting the regression coefficients for the interaction term obtained from the coefficient tables. Regression analysis was performed in this study to test the moderating effect of government policies on the relationship between productivity and economic growth.

Table 7 shows the regression between all integrated variable (independent and interaction) to examine the 
moderation effect on the relationship between productivity and government policies on economic growth. The adjusted coefficient of determination of the model is $R^{2} 0.560$ with $p$-value $<0.01$. As a result, the interaction term (Prod X GP) was significantly related to economic growth. The Model showed that $56 \%$ of economic growth is related to independent variables (productivity and interaction with government polices). Results in model Table 7 appear to confirm $\mathrm{H}_{6}$.

Table 7. The moderating effect of government policies on productivity and Economic growth

\begin{tabular}{|c|c|c|c|c|c|c|c|}
\hline \multirow{2}{*}{$\begin{array}{l}\text { Model } \\
1 \\
\text { ANOVA }\end{array}$} & \multirow[t]{2}{*}{$\begin{array}{l}\text { R } \\
075^{\mathrm{a}}\end{array}$} & \multicolumn{2}{|l|}{ R Square } & \multicolumn{2}{|c|}{$\begin{array}{l}\text { Adjusted R } \\
\text { Square }\end{array}$} & \multicolumn{2}{|l|}{$\begin{array}{l}\text { Std. Error } \\
\text { of the } \\
\text { estimate }\end{array}$} \\
\hline & & 0.564 & & \multicolumn{2}{|l|}{0.560} & \multicolumn{2}{|l|}{74.795} \\
\hline & & Sum of square & df & $\begin{array}{l}\text { Mean } \\
\text { square }\end{array}$ & $\mathrm{F}$ & \multicolumn{2}{|l|}{ Sig. } \\
\hline & Regression & 7322.607 & 1 & 7322.607 & 120.519 & \multirow{2}{*}{\multicolumn{2}{|c|}{$0.00^{\mathrm{b}}$}} \\
\hline & Residual & 5650.593 & 93 & 60.759 & & & \\
\hline & Total & 12973.200 & \multicolumn{4}{|c|}{ Coefficients } & \\
\hline & & $\begin{array}{l}\text { Unstandardized } \\
\text { B }\end{array}$ & \multicolumn{2}{|c|}{$\begin{array}{l}\text { Coefficients } \\
\text { Std. Error }\end{array}$} & $\begin{array}{l}\text { Standardized } \\
\text { Coefficients } \\
\text { Beta }\end{array}$ & $\mathrm{t}$ & Sig \\
\hline & Constant) & 34.378 & \multirow{2}{*}{\multicolumn{2}{|c|}{$\begin{array}{l}3.095 \\
0.001\end{array}$}} & & 11.108 & 0.000 \\
\hline & Infrastructure & 0.004 & & & 0.751 & 10.978 & 0.000 \\
\hline
\end{tabular}

a. DV: Economic growth

b. Predictors: (Constant) ProdxGP

\section{$H_{3}:$ There is positive effect of competiveness on economic growth}

To test the $\left(\mathrm{H}_{3}\right)$, the regression analysis for competiveness was conducted to determine the proportion of economic growth (dependent variable) which would be predicted by competiveness (independent variable). The model seems to be reliable ( $\mathrm{p}$-value for $\mathrm{F}<0.01$ and adjusted R-square of 0.532 . The Model showed that 53.2\% of economic growth is related to competiveness. Therefore, competiveness is a predictor of economic growth as shown in table 8. Results in model Table 8 appear to confirm $\mathrm{H}_{3}$.

Table 8. Regression results of competiveness and Economic Growth

\begin{tabular}{|c|c|c|c|c|c|c|c|}
\hline \multirow{2}{*}{$\begin{array}{l}\text { Model } \\
1 \\
\text { ANOVA }\end{array}$} & \multirow[t]{2}{*}{$\begin{array}{l}\mathbf{R} \\
0733^{\mathrm{a}}\end{array}$} & \multicolumn{2}{|l|}{ R Square } & \multicolumn{2}{|c|}{$\begin{array}{l}\text { Adjusted R } \\
\text { Square }\end{array}$} & \multicolumn{2}{|c|}{$\begin{array}{l}\text { Std. } \\
\text { of thror } \\
\text { of the } \\
\text { estimate }\end{array}$} \\
\hline & & 0.537 & & \multicolumn{2}{|l|}{0.532} & \multicolumn{2}{|c|}{8.038} \\
\hline & & Sum of square & df & \multirow{4}{*}{$\begin{array}{l}\text { Mean } \\
\text { square } \\
6964.376 \\
64.611\end{array}$} & $\mathrm{~F}$ & \multicolumn{2}{|l|}{ Sig. } \\
\hline & Regression & 6964.376 & 1 & & 207.789 & $0.00^{\mathrm{b}}$ & \\
\hline & Residual & 6008.824 & 93 & & & & \\
\hline & Total & 12973.200 & 94 & & & & \\
\hline & & $\begin{array}{l}\text { Unstandardized } \\
\text { B }\end{array}$ & \multicolumn{2}{|c|}{$\begin{array}{l}\text { Coefficients } \\
\text { Std. Error }\end{array}$} & $\begin{array}{l}\text { Standardized } \\
\text { Coefficients } \\
\text { Beta }\end{array}$ & $\mathrm{t}$ & Sig \\
\hline & Constant) & 18.774 & \multirow{2}{*}{\multicolumn{2}{|c|}{$\begin{array}{l}4.737 \\
0.097\end{array}$}} & & 9.964 & 0.000 \\
\hline & Infrastructure & 1.005 & & & 0.733 & 10.382 & 0.000 \\
\hline
\end{tabular}

a. DV: Economic growth

b. Predictors: (Constant) Competiveness

\section{$H_{7}$ : The Relationship between Competiveness and economic growth moderated by government policies.}

This study identified government polices use as the moderator variable affecting the relationship between competiveness (independent variable) and economic growth (dependent variable) among the logistic service firms in Oman. Using the moderated multiple regression (MMR) analysis in this study, the moderating effect of 
the variable (interaction term) was analyzed by interpreting the $\mathrm{R}^{2}$ change in the models obtained from the model summaries and by interpreting the regression coefficients for the interaction term obtained from the coefficient tables. Regression analysis was performed in this study to test the moderating effect of government policies on the relationship between competiveness and economic growth.

Table 9 shows the regression between all integrated variable (independent and interaction) to examine the moderation effect on the relationship between competiveness and government policies on economic growth. The adjusted coefficient of determination of the model is $R^{2} 0.607$ with p-value $<0.01$. As a result, the interaction term (Compt X GP) was significantly related to economic growth. The Model showed that $60.7 \%$ of economic growth is related to independent variables (competiveness and interaction with government polices). Results in model Table 9 appear to confirm $\mathrm{H}_{7}$.

Table 9. The moderating effect of government policies on competiveness and Economic growth

\begin{tabular}{|c|c|c|c|c|c|c|c|}
\hline Model & $\mathrm{R}$ & R Square & & $\begin{array}{l}\text { Adjusted F } \\
\text { Square }\end{array}$ & & $\begin{array}{l}\text { Std. Error } \\
\text { of the } \\
\text { estimate }\end{array}$ & \\
\hline \multirow{5}{*}{$\begin{array}{l}1 \\
\text { ANOVA }\end{array}$} & $0.782^{\mathrm{a}}$ & 0.612 & & 0.607 & & 7.363 & \\
\hline & & Sum of square & df & $\begin{array}{l}\text { Mean } \\
\text { square }\end{array}$ & $\mathrm{F}$ & Sig. & \\
\hline & Regression & 7933.369 & 1 & 7933.369 & 146.394 & $0.00^{\mathrm{b}}$ & \\
\hline & Residual & 5039.831 & 93 & 54.192 & & & \\
\hline & Total & 12973.200 & 94 & & & & \\
\hline \multirow{3}{*}{ Coefficients } & & $\begin{array}{l}\text { Unstandardized } \\
\text { B }\end{array}$ & \multicolumn{2}{|c|}{$\begin{array}{l}\text { Coefficients } \\
\text { Std. Error }\end{array}$} & $\begin{array}{l}\text { Standardized } \\
\text { Coefficients } \\
\text { Beta }\end{array}$ & $\mathrm{t}$ & Sig \\
\hline & Constant) & 32.448 & \multirow{2}{*}{\multicolumn{2}{|c|}{$\begin{array}{l}2.970 \\
0.001\end{array}$}} & & 10.926 & 0.000 \\
\hline & Infrastructure & 0.008 & & & 0.782 & 12.099 & 0.000 \\
\hline
\end{tabular}

a. DV: Economic growth

b. Predictors: (Constant) ComptxGP

\section{$H_{4}:$ There is positive effect of Technological Advancement on economic growth}

To test the $\left(\mathrm{H}_{4}\right)$, the regression analysis for technological advancement was conducted to determine the proportion of economic growth (dependent variable) which would be predicted by technological advancement (independent variable). The model seems to be reliable (p-value for $\mathrm{F}<0.01$ and adjusted R-square of 0.563 . The Model showed that $56.3 \%$ of economic growth is related to technological advancement. Therefore, technological advancement is a predictor of economic growth as shown in table 10. Results in model Table 10 appear to confirm $\mathrm{H}_{4}$.

Table 10. Regression results of technology advancement and Economic Growth

\begin{tabular}{|c|c|c|c|c|c|c|c|}
\hline Model & $\mathbf{R}$ & R Square & & \multicolumn{2}{|l|}{$\begin{array}{l}\text { Adjusted R } \\
\text { Square }\end{array}$} & \multicolumn{2}{|l|}{ Std. Error of the estimate } \\
\hline & $0.753^{\mathrm{a}}$ & 0.568 & & 0.563 & & 7.766 & \\
\hline & & Sum of square & df & Mean square & $\mathrm{F}$ & Sig. & \\
\hline & Regression & 7364.251 & 1 & 7.364 .251 & 122.104 & $0.00^{\mathrm{b}}$ & \\
\hline & Residual & 5608.949 & 93 & 60.311 & & & \\
\hline & Total & 12973.200 & 94 & & & & \\
\hline \multicolumn{8}{|c|}{ Coefficients } \\
\hline & & $\begin{array}{l}\text { Unstandardized } \\
\text { B }\end{array}$ & \multicolumn{2}{|c|}{$\begin{array}{l}\text { Coefficients } \\
\text { Std. Error }\end{array}$} & $\begin{array}{l}\text { Standardized } \\
\text { Coefficients } \\
\text { Beta }\end{array}$ & $\mathrm{t}$ & Sig \\
\hline & Constant) & 11.244 & \multicolumn{2}{|c|}{5.126} & & 2.193 & 0.031 \\
\hline & Infrastructure & 1.811 & \multicolumn{2}{|c|}{0.164} & 0.753 & 11.050 & 0.000 \\
\hline
\end{tabular}

a. DV: Economic growth

b. Predictors: (Constant) Technology advancement 


\section{$H_{8}:$ The Relationship between technological advancement and economic growth moderated by government policies.}

This study identified government polices use as the moderator variable affecting the relationship between technological advancement (independent variable) and economic growth (dependent variable) among the logistic service firms in Oman. Using the moderated multiple regression (MMR) analysis in this study, the moderating effect of the variable (interaction term) was analyzed by interpreting the $\mathrm{R}^{2}$ change in the models obtained from the model summaries and by interpreting the regression coefficients for the interaction term obtained from the coefficient tables. Regression analysis was performed in this study to test the moderating effect of government policies on the relationship between technological advancement and economic growth.

Table 11 shows the regression between all integrated variable (independent and interaction) to examine the moderation effect on the relationship between technological advancement and government policies on economic growth. The adjusted coefficient of determination of the model is $R^{2} 0.622$ with $p$-value $<0.01$. As a result, the interaction term (TechAdvxGP) was significantly related to economic growth. The Model showed that $62.2 \%$ of economic growth is related to independent variables (technological advancement and interaction with government polices). Results in model Table 11 appear to confirm $\mathrm{H}_{8}$.

Table 11. The moderating effect of government policies on technology advancement and Economic growth

\begin{tabular}{|c|c|c|c|c|c|c|c|}
\hline Model & $\mathbf{R}$ & R Square & & $\begin{array}{l}\text { Adjusted } \\
\text { Square }\end{array}$ & & $\begin{array}{l}\text { Std. Error } \\
\text { of the } \\
\text { estimate }\end{array}$ & \\
\hline \multirow{5}{*}{$\begin{array}{l} \\
\text { ANOVA }\end{array}$} & $0.791^{\mathrm{a}}$ & 0.626 & & 0.622 & & 7.224 & \\
\hline & & Sum of square & df & $\begin{array}{l}\text { Mean } \\
\text { square }\end{array}$ & $\mathrm{F}$ & Sig. & \\
\hline & Regression & 8119.614 & 1 & 8119.614 & 155.581 & $0.00^{\mathrm{b}}$ & \\
\hline & Residual & 4853.586 & 93 & 52.189 & & & \\
\hline & Total & 12973.200 & 94 & & & & \\
\hline \multirow{3}{*}{ Coefficients } & & $\begin{array}{l}\text { Unstandardized } \\
\text { B }\end{array}$ & \multicolumn{2}{|c|}{$\begin{array}{l}\text { Coefficients } \\
\text { Std. Error }\end{array}$} & $\begin{array}{l}\text { Standardized } \\
\text { Coefficients } \\
\text { Beta }\end{array}$ & $\mathrm{t}$ & Sig \\
\hline & Constant) & 30.490 & \multirow{2}{*}{\multicolumn{2}{|c|}{$\begin{array}{l}3.035 \\
0.001\end{array}$}} & & 10.046 & 0.000 \\
\hline & Infrastructure & 0.014 & & & 0.791 & 12.473 & 0.000 \\
\hline
\end{tabular}

a. DV: Economic growth

b. Predictors: (Constant) TechAdvxGP

\section{Discussion}

\subsection{Infrastructure and Economic Growth}

The first objective of this research was to evaluate the relationship between infrastructure and the economic growth of Oman. In general, infrastructure problems research is considering only a narrow part of the infrastructure capital that is in public ownership. This research focus on 5 key logistic service sectors which include: (1) air transport service, (2) marine transport service, (3) shipping and port agent, (4) Land transport, (5) transport agent. The research finding show that the correlation of infrastructure and the economic growth of Oman was significant enough to show the correlation of two variables. The finding of research is in line with research conducted by Jin Zhoua et al., (2021). They argued that Infrastructure investment is a typical fiscal tool to stimulate economic growth and economic counter-cyclical djustments, well developed infrastructure reduces regional distances, integrates national markets, and enhances connectivity with other economies. It is considered that infrastructure development impacts economic activities in three ways (Sahoo and Dash 2009 cited in Jin Zhoua et al (2021); Saygılı and Özdemir 2020) firstly, it directly contributes to production and employment through the increase of physical intermediates, such as transport and communication. Secondly, it increases human capital and improves people's social lives by providing better facilities such as education and health. Thirdly, it improves financial facilities such as monetary transactions, loans, and other services. Improvement in one type of infrastructure complements developing other forms of economic infrastructure (Jin Zhoua et al (2021). Moreover, considerable literature indicates that continuous large scale infrastructure investment has softened the proportion of capital-output. It reduced investment efficiency and economic resource depletion 
(Banergee, Duflo, and Qian 2020; Cai and Ru 2016; Ouattara and Zhang 2019).

Some studies (Jin Zhoua et al (2021) discussed the solitary role of infrastructure in terms of growth efficiency, or sustainability, there is currently limited literature available that systematically attempts to evaluate infrastructure's role from the perspective of growth quality. To measure the economic growth quality, a comprehensive index is constructed by considering the efficiency, stability, and sustainability of economic growth. An objective and rigorous examination of growth quality using historical data can provide useful references and policymaking judgements.

This research result also supported by Tatyana Palei (2014) Assessing the impact of infrastructure on economic growth and global competitiveness. She argued the impact of infrastructure on economic growth and the competitiveness of domestic producers can be concluded that the impact of infrastructure is expressed as follows: (1) Infrastructure enables businesses to generate additional production capacity, reduce the cost of inputs in the production and transaction costs. This is called a direct impact performance; (2) Infrastructure increases the productivity of workers, and this effect is known as an indirect effect; (3) The impact of infrastructure on economic growth achieves in the initial period of construction work: creating jobs in construction and related industries. Investments in infrastructure require maintenance; it further increases the number of created jobs; (4) The infrastructure also has a positive impact on education and health: good health and a high level of education of labour causes economic growth; (5) Infrastructure contributes to the accession of the poor and undeveloped areas to the core business activities, public communications, which can raise the value of their assets, and increase human capital.

Infrastructure in Oman considers Transport and Communications sector as an essential building block for the country's basic infrastructure. The road network links extensively to all parts of the sultanate (MoTC 2009. Plans are underway to upgrade the country's airports and ports, and to augment the over-ground transport network with the development of a national and regional rail network (Oman Infrastructure Report Q2 2009). The telecom sector has witnesses a good growth, with penetration of mobile phones reaching almost 100\% (Belwal and Belwal 2009). The government has taken initiatives to break its monopoly in this sector (ITU 2009).

\subsection{Productivity and Economic Growth}

The second objective of this research was to evaluate the relationship between productivity and the economic growth of Oman. The research findings show that the correlation of productivity and the economic growth of Oman was significant to show the correlation of two variables. According to research finding carried out by Surya, et al., (2021) economic growth have significant impact on productivity. They argue that economic growth strategy based on technological innovation is recommended for government decision making as an effort to increase the productivity (Surya et al., (2021). However, this research investigates the linkage between productivity as independent variable and economic growth as dependent variable.

Robert F. DeLucia (2021) described that Strong growth in labour productivity enhances the potential growth rate of an economy. It also increases the potential duration of an expansion cycle by enabling aggregate demand to increase without physical limitations from supply bottlenecks. The ultimate source of rising per capita real wages is rapid growth in productivity. Workers enjoy rising real wage increases as compensation for their contribution to faster growth in aggregate output.

The synchronized nature of the productivity slowdown after the global financial crisis (GFC) raises questions about the role of common factors or spill overs, and the extent to which they will again operate during the pandemic-driven recession in 2020. The nature of the post-global financial crisis (GFC) slowdown and its drivers has proved controversial. Some have attributed the weakness in productivity growth to waning technological progress as innovations regarded as "low-hanging fruit" have already been developed, leaving only innovations with lower marginal gains (Gordon 2012; Gordon and Sayed 2019). Others regard the slowdown in productivity growth as a "pause," given the time delay between radical new digital technologies being developed and then incorporated into production processes (Brynjolfsson, E., D. Rock, and C. Syverson. 2020).

The COVID-19 pandemic threatens to weigh on longer-run trends that could impede productivity growth in emerging market and developing economies (EMDEs). Over the past decade, the prospects for further trade integration have diminished, and the expansion of global value chains has lost momentum. Sharp declines in global trade and investment, amid the pandemic, could accelerate these trends. For many countries, they will mean subdued activity, instability, and new pressures on governments (World Bank Group (2021) 
The finding of this research also related with research finding from Suna Korkmaz \& Oya Korkmaz, (2017). They conducted the research on the Relationship between Labour Productivity and Economic Growth in OECD Countries.

The finding of this research also supported by (Koji Nakamura, Sohei Kaihatsu, Tomoyuki Yagi (2018). They found that Labour productivity in major advanced countries has been experiencing a slowdown in recent years. This is mainly affected by the slowdown of Total Factor Productivity (TFP). In Japan, there are two reasons behind the slowdown: first, technology and ideas accumulated by research and development $(R \& D)$ and management resources such as capital and labour are not utilized efficiently; and second, these resources are not efficiently reallocated among corporations.

\subsection{Competiveness and Economic Growth}

The third objective of this research was to investigate the relationship between competiveness and the economic growth of Oman. The research findings show that the correlation of competiveness and the economic growth of Oman were significant to show the correlation of two variables. This finding supported by previous study for instance, research conducted by Aleksandra Kordalska and Magdalena Olczyk (2015). They argue that global competiveness is a reliable predictor of economic growth or whether the growth rate can be believed to predict the global competitiveness of a country. However, other researcher (Zagorsekova, et al (2018) investigates the Competitiveness and Economic Growth in the European Union. The paper focuses on competitiveness at the national level and on the impact of competitiveness on economic growth. They look at the relationship between competitiveness and economic growth based on the data from the European Union member states. The competitiveness of the economies is measured by the Global Competitiveness Index, which is published by the World Economic Forum. The European Union member states show significant differences in competitiveness. In the sample examined, the positive relationship between the level of competitiveness and economic growth was not confirmed.

This research is in line with research carried out by Romana Korez-Vide and Polona Tominc (2016). They investigated the competitiveness, entrepreneurship and economic growth. They concluded that a country's economic growth and consequently the standard of living of its population are related to many factors that are inside or outside the control of policymakers, institutions, companies and individuals. Although variously conceptualized and measured, a country's competitiveness comprises endogenous and exogenous variables of economic growth. The key goal of their study was to find out if a country's competitiveness and its economic growth is related. As a measure of competitiveness, they used the World Economic Forum's Global Competitiveness Index, as a measure of economic growth, however, GDP per capita was used.

\subsection{Technology Advancement and Economic Growth}

The fourth objective of this research was to assess the relationship between technological advancement and the economic growth of Oman. The research finding show that the correlation of competiveness and the economic growth of Oman was significant to show the correlation of two variables. This finding is related with previous research for instance, research conducted by James Broughel and Adam Thierer (2019). They argued that Technological advancement is a fundamental driver of economic growth and human progress.

The finding of this research is related with research conducted by Krume Nikoloski (2016). He found that there was a significant linkage between technology and economic growth. Gurgul, Henry and Lach, Łukasz (2012) also investigate the technological progress and economic growth: evidence from Poland. The main goal of their research was the examination of causal interdependencies between different measures of technological progress and GDP in Poland on the basis of quarterly data for the period Q1 2000 - Q4 2009. They performed the research on the number of patents registered in The Patent Office of Poland as well as on R\&D expenditures. The empirical research was performed in a three-dimensional framework with employment chosen as an additional variable, since a two-dimensional approach involving only GDP and one of the measures of technological progress may be seriously biased due to the omission of important variables. In order to conduct a comprehensive causality analysis, they applied both traditional methods as well as some recently developed econometric tools.

\subsection{The Moderating Effect}

The moderated multiple regression test was conducted to determine the regression on government policies by integration in logistic sector (infrastructure, productivity, competiveness and technological advancement) and the interaction of moderating variables with independent variable individually (Inf X GP, Prod X GP, Comp X GP and TA X GP). The results show that, there are significances of the government policies as moderators of the 
relationship between infrastructure, productivity, competiveness and technological advancement. The highest moderating role of government policies on the relationship between infrastructure, productivity, competiveness and technological advancement on economic growth is infrastructure with $\mathrm{R}^{2} 0.630$, followed by technology advancement $R^{2} 0.622$, competiveness $R^{2} 0.607$ competiveness and productivity $R^{2} 0.560$ respectively.

This finding supported by previous study for example research conducted by Desy Tri Anggarini \&Ani Rakhmanita (2020). Their finding showed the government policies has a significant role for supporting National Economic Recovery Program in the Context of Supporting State Financial Policy for Handling Corona Virus Disease 2019 (Covid-19). Fitriani et al (2021) investigated the Government Policy Strategies in Sustaining Economic Growth in the Covid-19 Pandemic Era. They argued that to keep the economy growing positively, the government issued several stimuli both in the form of direct cash assistance and various programs to alleviate the costs of business actors (such as rescheduling bank installments), exemption from paying taxes, electricity subsidies, pulse subsidies, and others. Fiscal, monetary, and financial stimulus policies will work effectively if carried out simultaneously and in a coordinated manner. The spread of the Covid-19 pandemic has been minimized if the community complies and implements health protocols recommended by the government. Economic activities are closely related to the development conditions of the Covid-19 virus.

\section{Conclusion}

This study investigates the linkage of various factors of integration in logistic sector on economic growth. The study is also examining the role of government policy on the relationship between the factors of integration and the economic growth.

The results show that statistically significant positive relationship between infrastructure, productivity, competiveness and technology advancement on economic growth. These results appear to confirm $\left(\mathrm{H}_{1}, \mathrm{H}_{2}, \mathrm{H}_{3}\right.$ and $\left.\mathrm{H}_{4}\right) \cdot \mathrm{H}_{1}$ : There is positive effect of Infrastructure on economic growth, $\mathrm{H}_{2}$ : There is positive effect of productivity on economic growth, $\mathrm{H}_{3}$ : There is positive effect of competiveness on economic growth, $\mathrm{H}_{4}$ : There is positive effect of Technological Advancement on economic growth. These results suggest that infrastructure, productivity, competiveness, technological advancement has the ability to increase the economic growth.

This research also finds that moderating effect of government policies on relationship between infrastructure, productivity, competiveness and technology advancement on economic growth. These results appear to confirm $\left(\mathrm{H}_{5}, \mathrm{H}_{6}, \mathrm{H}_{7}\right.$ and $\left.\mathrm{H}_{8}\right) . \mathrm{H}_{5}$ : The Relationship between infrastructure and economic growth moderated by government policies, $\mathrm{H}_{6}$ : The Relationship between productivity and economic growth moderated by government policies, $\mathrm{H}_{7}$ : The Relationship between Competiveness and economic growth moderated by government policies, $\mathrm{H}_{8}$ : The Relationship between technological advancement and economic growth moderated by government policies. These results suggest that government polices has significant role on the relationship between infrastructure, productivity, competiveness, technological advancement on economic growth.

\section{References}

Agénor, P. R., \& Moreno-Dodson, B. (2006). Public infrastructure and growth: new channels and policy implications. Banca d'Italia, Italia. https://doi.org/10.1596/1813-9450-4064

Ahrend, R. (2006). Russian industrial restructuring: Trends in productivity, competitiveness and comparative advantage. Post-Communist Economies, 18, 277-295. https://doi.org/10.1080/14631370600881770

Anwar, M., Khan, S. Z., \& Khan, N. U. (2018) Intellectual Capital, Entrepreneurial Strategy and New Ventures Performance: Mediating Role of Competitive Advantage. Bus. Econ. Rev. 10, 63-94. https://doi.org/10.22547/BER/10.1.3

Astra, A. E. (2014). Labour productivity, economic growth and global competitiveness in post-crisis period. 19th International Scientific Conference; Economics and Management 2014, ICEM 2014, 23-25. April 2014, Riga, Latvia. Procedia - Social and Behavioural Sciences, 156, 317-321. https://doi.org/10.1016/j.sbspro.2014.11.195

Baldwin, J. R., \& Dixon, J. (2008), Infrastructure Capital: What is it? Where is it? How much of it is there? Canadian Productivity Review. No 16. Ottawa: Statistics Canada. https://doi.org/10.2139/ssrn.1507883

Barney, J., \& Hesterly, W. S. (2006). Strategic Management and Competitive Advantage. Concepts (2nd ed.). New Jersey: Prentice Hall.

Bartlett, C. A., \& Ghoshal, S. (1990). Managing innovation in the transnational corporation, in: Bartlett, C., Doz, Y., Hedlund, G. (eds.), Managing the Global Firm, London: Routledge, 215-255.

Berger, T. (2008). Concepts on National Competitiveness. Journal of International Business and Economy, 9(1). 
https://doi.org/10.51240/jibe.2008.1.5

Berger, T., \& Bristow, G. (2009). Competitiveness and the Benchmarking of Nations - A Critical Reflection. International Advances in Economic Research, 15(4). https://doi.org/10.1007/s11294-009-9231-x

Boltho, A. (1996). The assessment: international competitiveness. Oxford Review of Economic Policy, 12(3). https://doi.org/10.1093/oxrep/12.3.1

Bourlakis, C., \& Bourlakis, M. (2005). Information technology safeguards, logistics asset specificity and fourth-party logistics network creation in the food retail chain. Journal of Business \& Industrial Marketing, 20(2), 88-98. https://doi.org/10.1108/08858620510583687

Calderón, C. E. M., \& Servén, L. (2011). Is Infrastructure Capital Productive? A Dynamic Heteregenous Approach, World Bank Policy Research Working Paper 5682. https://doi.org/10.1596/1813-9450-5682

Canning, D., \& Pedroni, P. (1999). Infrastructure and Long-Run Economic Growth. CAER II Discussion Paper No. 57. Harvard Institute for International Development, US.

Cooke, P. N., Heidenreich, M., \& Braczyk, H. J. (Eds.) (2004). Regional Innovation Systems: The Role of Governance in a Globalized World. Psychology Press: Hove, UK, 2004.

Davies, H., \& Ellis, P. D. (2000). Porter's 'Competitive Advantage of Nations': Time for a final judgment? Journal of Management Studies, 37(8). https://doi.org/10.1111/1467-6486.00221

DC. (2001). Destination Competitiveness: Development of a Model with Application to Australia and the Republic of Korea, An Australian Government Report.

De la Croix, D., \& Delavallade, C. (2006). Growth, public investment and corruption with failing institutions. Working Paper 2007-61. Verona, Italy: Society for the Study of Economic Inequality. https://doi.org/10.2139/ssrn.970305

Demurger, S. (2001). Infrastructure Development and Economic Growth: An Explanation for Regional Disparities in China? Journal of Comparative Economics, 29, 95-117. https://doi.org/10.1006/jcec.2000.1693

Desai, D. A., \& Shaikh, A. J. A. (2018). Reducing failure rate at high voltage (HV) testing of insulator using Six Sigma methodology. Int. J. Prod. Perform. Manag. 67, 791-808. https://doi.org/10.1108/IJPPM-11-2016-0235

Dobrinsky, R., \& Havlik, P. (2014). Economic convergence and structural change: The role of transition and EU accession. Vienna: The Vienna Institute for International Economic Studies.

Doh, S., \& Kim, B. (2014). Government support for SME innovations in the regional industries: The case of government financial support program in South Korea. Res. Policy 2014, 43, 1557-1569. https://doi.org/10.1016/j.respol.2014.05.001

Dunning, J. H. (1992). Multinational enterprises and the global economy. Woking- ham, UK and Reading, MA: Addison-Wesley Publishing Company.

Dunning, J. H. (1993). The globalization of business. London and New York: Routledge.

Eraydn. A. (2001). Yeni Ekonomi'nin Getirdii Frsat ve Riskler, Toplumsal ve Mekansal Açdan. Yeni Ekonomi El Kitab, T.C. Merkez Bankas, Ankara.

Feltenstein, A., \& J. Ha (1995). The Role of Infrastructure in Mexican Economic Reform. The World Bank Economic Review, 9(2), 287-304. https://doi.org/10.1093/wber/9.2.287

Ganna, K., \& Olga, V. (2013). Ganna Kharlamova, Olga Vertelieva, The International Competitiveness of Countries: Economic-Mathematical Approach. Economics \& Sociology, 6(2), 39-52. https://doi.org/10.14254/2071-789X.2013/6-2/4

Grubesic, T. H. (2009). The Management and Measurement of Infrastructure: Performance, Efficiency and Innovation. Growth and Change, 1, 184-187. https://doi.org/10.1111/j.1468-2257.2008.00469.x

Gupta, J., \& Gregoriou, A. (2018) Impact of market-based finance on SMEs failure. Econ. Mode, 69, 13-25. https://doi.org/10.1016/j.econmod.2017.09.004

Gupta, N., \& Mirchandani. (2018) A. Investigating entrepreneurial success factors of women-owned SMEs in UAE. Manag. Decis. 56, 219-232. https://doi.org/10.1108/MD-04-2017-0411

Gurgul, H., \& Lach, Ł. (2012). Technological progress and economic growth: evidence from Poland. Munich 
Personal RePEc Archive.

Heidenreich, (2003). M. Regional inequalities in the enlarged Europe. J. Eur. Soc. Policy 2003, 13, 313-333. https://doi.org/10.1177/09589287030134001

Hirshman, A. O. (1958). The Strategy of Economic Development. Westview Press.

Howells. (2005). J. Innovation and regional economic development (2005): A matter of perspective. Res. Policy 2005, 34, 1220-1234. https://doi.org/10.1016/j.respol.2005.03.014

Hülya, K. Ç. (2015). Technological Change and Economic Growth. World Conference on Technology, Innovation and Entrepreneurship. Procedia - Social and Behavioral Sciences, 195, 649-654. https://doi.org/10.1016/j.sbspro.2015.06.174

Ivo, D. L., \& Luc, S. (1999). The Impact of Technology on Economic Growth: Some New Ideas and Empirical Considerations. https://doi.org/10.26481/umamer.1999017

Joo, H. Y., \& Suh, H. (2017). The Effects of Government Support on Corporate Performance Hedging against International Environmental Regulation. Sustainability 2017, 9, 1980. https://doi.org/10.3390/su9111980

Joseph, P. (1998). Productivity Management: A practical Handbook. Geneva: International Labour Office - ILO, 1998.

Kathuria, V., Raj, R. S. N., \& Sen, K. (2013). Productivity Measurement in Indian Manufacturing: A Comparison of Alternative Methods. Journal of Quantitative Economics, 11(1\&2), 148-179.

Koji, N., Sohei, K., \& Tomoyuki, Y. (2018). Productivity Improvement and Economic growth. Bank of Japan 2-1-1 Nihonbashi-Hongokucho, Chuo-ku, Tokyo 103-0021, Japan. No.18-E-10 May 2018

Krugman, P. (1992). The Age of Diminished Expectations: US Economic Policy in the 1980s. MIT Press, Cambridge.

Krume, N. (2016). Technology and Economic Development: Retrospective. JPMNT) Journal of Process Management - New Technologies, International, 4(4), 2016. https://doi.org/10.5937/jouproman4-11468

Lall, S. (2001). Competitiveness Indices and Developing Countries: An Economic Evaluation of the GlobalCompetitiveness Report. World Development, 29(9).

https://doi.org/10.1016/S0305-750X(01)00051-1

Lewis, A. (1954, may), Economic Development with Unlimited Supplies of Labour. Manchester School, 22(2). https://doi.org/10.1111/j.1467-9957.1954.tb00021.x

Lewis, A. (1956). The Theory of Economic Growth. George Allen \& Unwin Ltd, Great Britain

Lieb, R., \& Bentz, B. A. (2005). The North American third-party logistics industry in 2004: the provider CEO perspective. International Journal of Physical Distribution \& Logistics Management, 35, 595-611. https://doi.org/10.1108/09600030510623357

Lieberman, M. B., \& Kang, J. (2008). How to Measure Company Productivity Using Value-Added: A Focus on

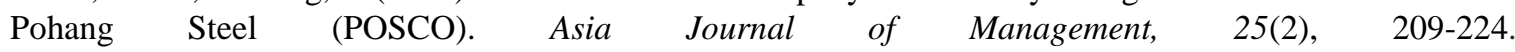
https://doi.org/10.1007/s10490-007-9081-0

Lukasz, P. (2014). Review of Theories And Models Of Economic Growth. Comparative Economic Research, 17(1). https://doi.org/10.2478/cer-2014-0003

Masso, J., \& Vahter, P. (2012). The link between innovation and productivity in Estonia's services sector. Service Industries Journal, 32, 2527- 2541. https://doi.org/10.1080/02642069.2011.600444

Michelle, O., Qiang, L., Sue, M., \& Susanne, T. (2011). Measuring Infrastructure Performance: Development of a National Infrastructure Index. Public Works Management \& Policy. Retrieved from http://pwm.sagepub.com/

Munnell, A. H. (1990a). Why Has Productivity Declined? Productivity and Public Investment. New England Economic Review, 3-22.

Munnell, A. H. (1990b). How Does Public Infrastructure Affect Regional Economic Performance. New England Economic Review, 11-32.

Novi, M., Oki, H., \& Myrnawati, S. (2014). The role of infrastructure on economic growth in Indonesia. Economic Researcher in BRE DKM, Indonesian Bank (Bank Indonesia).

OECD. (2001). Measuring Productivity, Measurement of Aggregate and Industry-Level Productivity Growth. 
Retrieved from https://www.oecd.org/std/productivity-stats/2352458.pdf

Olczyk, M. (2008). Konkurencyjnosc - Teoria i praktyka. Warszawa: Wydawnictwo Fachowe CEDEWU.

Owyong, D. T. (2001). Productivity Growth: Theory and Measurement. APO Productivity Journal, 19-29. Retrieved from http://www.apo-tokyo.org/productivity/016_prod.pdf

Porter, M. E. (1990). The Competitive Advantage of Nations. The Free Press, New York. https://doi.org/10.1007/978-1-349-11336-1

Prasetyo, R. B. (2008). Ketimpangan dan Pengaruh Infrastruktur terhadap Pembangunan Ekonomi Kawasan Barat Indonesia (KBI). Departemen Ilmu Ekonomi, Fakultas Ekonomi dan Manajemen, Institut Pertanian Bogor.

Prasetyo, R. B., \& M. Firdaus, (2009). Pengaruh Infrastruktur pada Pertumbuhan Ekonomi Wilayah Indonesia. Jurnal Ekonomi and Kebijakan Pembangunan, 2(2), 222-236.

Prud'homme, R. (2005). Infrastructure and Development. Lessons of Experience. Proceedings of the 2004 Annual Bank conference on Development Economics, 153-181.

RepGraph Ltd, 2015, Logistics Industry Survey, UK logistics development.

Rhee, K., \& Pyo, H. (2010). Financial crisis and relative productivity dynamics in Korea: Evidence from firm-level data (1992-2003). Journal of Productivity Analysis, 34, 111-131. https://doi.org/10.1007/s11123-010-0177-z

Robert, G. K., \& Sergio, R. (1990). Public Policy and Economic Growth: Developing Neoclassical implication. National Bureau of Economic Research 1050 Massachusetts Avenue. Camridge, MA 012138. April 1990

Romana, K. V., \& Polona, T. (2016). Competitiveness, Entrepreneurship and Economic Growth. Springer International Publishing Switzerland 2016 P. Tra pczyn'ski et al. (eds.), Competitiveness of CEE Economies and Businesses.

Rugman, A. M. (1990). Global Corporate Strategy and Trade Policy. London and New York: Routledge.

Rugman, A. M. (1991). Diamond in the Rough. Business Quarterly, 55(3).

Rugman, A. M., \& D'Cruz, J. R. (1993). The 'Double Diamond' Model of International Competitiveness: the Canadian Experience. Management International Review, Special Issue, 33.

Rugman, Van den Broeck, J., \& Verbeke, A. (Ed.). (1995). Research in Global Strategic Management: Volume V. Beyond the Diamond. Greenwich, CT: JAI Press.

Schultz, T. (1981). Investing in People: The Economics of Population Quality. Berkeley: University of California Press. https://doi.org/10.1525/9780520318540

Seethepalli, K., Bramati, M. C., \& Veredas, D. (2008). How Relevant Is Infrastructure To Growth In East Asia? The world bank e-library. Research Working Papers No.: 4597. https://doi.org/10.1596/1813-9450-4597

Shonchoy, A. S., \& Junankar, P. N. (Raja), (2014). The informal labour market in India : transitory or permanent employment for migrants? IDE Discussion Papers, 461. Institute of Developing Economies, Japan External Trade Organization(JETRO). https://doi.org/10.1057/9781137555229_13

Smit, A. J. (2010). The Competitive Advantage of Nations: Is Porter's Diamond Framework a New Theory that Explains the International Competitiveness of Countries? Southern African Business Review, 14(1).

Solow, R. M. (1962). Technical Progress, Capital Formation, and Economic Growth. The American Review, 52(3), 76-86.

Stefan, D., \& Jeroen, C. J. M. van den Bergh (2017) Scientists' views on economic growth versus the environment: a questionnaire survey among economists and non-economists. Global Environmental Change.

Straub, S., Vellutini, C., \& Warlters, M. (2008). Infrastructure and economic growth in East Asia, Policy Research Working Paper Series 4589. https://doi.org/10.1596/1813-9450-4589

Suna, K., \& Oya, K. (2017). The Relationship between Labor Productivity and Economic Growth in OECD Countries. International Journal of Economics and Finance, 9(5). https://doi.org/10.5539/ijef.v9n5p71

Syverson, C. (2011). What Determines Productivity? Journal of Economic Literature, 49(2), 326-365. https://doi.org/10.1257/jel.49.2.326 
Tatyana, P. (2014). Assessing The Impact of Infrastructure on Economic Growth and Global Competitiveness. 2nd GLOBAL CONFERENCE on BUSINESS, ECONOMICS, MANAGEMENT and TOURISM, 30-31 October 2014, Prague, Czech Republic.

Taylor, T., Greenlaw, S. A., Dodge, E., \& Sonenshine, R. (2016). Principles of Economics. US: Rice University, Open Stax.

Tomasz, S., \& Aldona, Z. (2014) competiveness in the economic concepts, theories and empirical research. Oeconomia, 13(1), 91-108.

U.S. Chamber of Commerce. (2010a). Let's rebuild America: Infrastructure index-initiation phase report. Retrieved from http://www.uschamber.com/sites/default/files/lra/docs/ lraindexinitphasereport100406.pdf

Waverman, L. (1995). A Critical Analysis of Porter's Framework on the Competitive Advantage of Nations. https://doi.org/10.1016/S1064-4857(95)05004-3

Witkowski, K. (2017). Internet of things, big data, industry 4.0-innovative solutions in logistics and supply chains management. Procedia Engineering, 182, 763-769. https://doi.org/10.1016/j.proeng.2017.03.197

Wu, Y. (1999). Income Disparity and Convergence in China's Regional Economies. Department of Economics, University of Western Australia.

Yang, S., \& Ishtiaq, M. (2018). Anwar, M. Enterprise Risk Management Practices and Firm Performance, the Mediating Role of Competitive Advantage and the Moderating Role of Financial Literacy. J. Risk Financ. Manag, 11, 35. https://doi.org/10.3390/jrfm11030035

Yanuar, R. (2006). Kaitan Pembangunan Infrastruktur and Pertumbuhan Output serta Dampaknya terhadap Kesenjangan di Indonesia. Tesis Magister Sains. Program Pascasarjana IPB, Bogor.

Yeaple, S. R., \& Golub S. S. (2007). International Productivity Differences, Infrastructure, and Comparative Advantage. Review of International Economics, Wiley Blackwell, 15(2), 223-242. https://doi.org/10.1111/j.1467-9396.2007.00667.x

\section{Copyrights}

Copyright for this article is retained by the author(s), with first publication rights granted to the journal.

This is an open-access article distributed under the terms and conditions of the Creative Commons Attribution license (http://creativecommons.org/licenses/by/4.0/). 